\title{
Detection of human papilloma virus in the cervical Pap smears and with polymerase chain reaction technique in the rural area of Western Maharashtra, India
}

\author{
Poorva Gurjar ${ }^{1}$, Nanda Patil ${ }^{2}$, Vijay Bonde ${ }^{2 *}$
}

${ }^{1} 3^{\text {rd }}$ year M.B.B.S. student, KIMS, Karad, Maharashtra, India

${ }^{2}$ Department of Pathology, KIMS, Karad, Maharashtra, India

Received: 04 June 2016

Accepted: 01 July 2016

*Correspondence:

Dr. Vijay Bonde,

E-mail: vijaybonde11@gmail.com

Copyright: (C) the author(s), publisher and licensee Medip Academy. This is an open-access article distributed under the terms of the Creative Commons Attribution Non-Commercial License, which permits unrestricted non-commercial use, distribution, and reproduction in any medium, provided the original work is properly cited.

\begin{abstract}
Background: Cervical cancer is the second most common cancer in women worldwide and the most common cancer causing death in developing countries. Recent studies have demonstrated the etiological role of human papilloma virus (HPV) in the development of cervical cancer. The oncogenic strains of HPV produce characteristic cytopathic effect in the cervical epithelial cells which can be recognized in the cervical Pap smears as well as tissue sections. However, definitive identification of virus is dependent on specific techniques like electron microscopy, staining of the capsule antigen with immunocytochemical techniques, identification of viral DNA by in situ hybridization and the most sensitive of all is the PCR technique based on DNA amplification. The objective of this study was to find out the HPV infection in cervical Pap smears and using polymerase chain reaction. To categorize the HPV infection into low risk and high risk group. And to find the association of low and high risk group HPV with squamous intraepithelial lesion and squamous cell carcinoma. And to clinicopathological correlation of high risk HPV.

Methods: A two months prospective study was carried from July 2015 to Aug 2015 in our institute to detect HPV infection by Pap smear method as well as using polymerase chain reaction.

Results: Total 36 cases were obtained within a prospective study period of 2 months. Per speculum examination did not reveal significant change in any of these cases. Taking PCR as a gold standard, sensitivity, specificity, positive and negative predictive value of Pap smear was determined.

Conclusions: Pap smears and HPV DNA testing with PCR play significant role in the early detection of cervical lesions where clinical examination has limitations. High risk HPV detection with the PCR technique can be used as a tool to identify the population at risk for subsequent development of cervical cancer.
\end{abstract}

Keywords: HPV, Pap smears, PCR

\section{INTRODUCTION}

Cervical cancer is the second most common cancer in women worldwide and the most common cancer causing death in developing countries. ${ }^{1}$ Approximately 510000 new cases of cervical cancer are detected annually causing 288000 deaths worldwide. ${ }^{2}$ In India there are 365.71 million women above the age of 15 years who are at risk of developing cervical cancer. ${ }^{3}$
Recent studies have demonstrated the etiological role of human papilloma virus (HPV) in the development of cervical cancer. Specific types of human papilloma virus $(16,18,31,33,35$, and 45$)$ are found in more than $90 \%$ cases of cervical cancer. ${ }^{4-6}$ These strains act as initiating agents in the pathogenesis of cervical cancer. The oncogenic strains of HPV produce characteristic cytopathic effect in the cervical epithelial cells which can 
be recognised in the cervical Pap smears as well as tissue sections.

However, definitive identification of virus is dependent on specific techniques like electron microscopy, staining of the capsule antigen with immunocytochemical techniques, identification of viral DNA by in situ hybridization and the most sensitive of all is the PCR technique based on DNA amplification. ${ }^{8}$

Conventional Pap smear is used currently for screening of cases of cervical cancer based on the viral cytopathic effects, but has a high rate of false negative results in the detection of HPV infection. ${ }^{9,10}$ Routine Pap smear cannot identify the high risk HPV types. Hence, new molecular biology tools with high sensitivity and specificity have been incorporated for early detection of these strains. Amongst these polymerase chain reaction (PCR) is considered more accurate.

The US food and drug administration (FDA) has approved the combination of cervical cytology and HPV DNA testing which is appropriate for women 30 years and older for the detection of HPV and cervical cancer.

The objective of this study was to find out the HPV infection in cervical Pap smears and using polymerase chain reaction. To categorize the HPV infection into low risk and high risk group. And to find the association of low and high risk group HPV with squamous intraepithelial lesion and squamous cell carcinoma. And to clinicopathological correlation of high risk HPV.

\section{METHODS}

The prospective study was carried out in our institute from July 2015 to August 2015 which included 36 cases.

\section{Inclusion criteria}

The symptomatic women above the age of 30 years coming to gynaecology OPD in our institute and willing for HPV DNA testing were selected for study.

The study was done after consent from ethical committee of our institute. Informed consent was taken from the patient and all the rules regarding ethics committee consideration were followed.

Pap Smears were prepared from the material and the slides were immersed in equal parts and 95\% alcohol and ether. The slides still wet were kept for 2 hours for fixation. Then Pap stain was done. The smears were taken by expert gynaecologists while reporting was done by expert cytopathologist. The cases were categorized as inadequate, inflammatory, atypical squamous cells with undetermined significance (ASCUS), low grade squamous intraepithelial lesion (LSIL), high grade squamous intraepithelial lesion (HSIL) and squamous cell carcinoma (SCC).
The material collected was sent for HPV DNA testing and genotyping to the molecular and genetic laboratory. Further processing and HPV typing was done by the senior research officer in the molecular and genetic laboratory by using PCR machine. Statistical analysis, i.e. sensitivity, specificity, positive and negative predictive value was determined.

\section{RESULTS}

Total 36 cases were obtained within a prospective study period of 2 months.

\section{PCR Results for HPV DNA testing}

Out of 36 cases, 6 were positive for HPV DNA (16.6\%).

High risk HPV type was seen in 2 cases $5.5 \%$, while rest 4 cases revealed low risk group HPV $11.1 \%$. Both cases of high risk HPV were HPV 16 positive. In 4 cases of low risk HPV, two cases each were positive for HPV 6 and 11 .

Among the two high risk HPV cases, one case revealed CIN (I), i.e. LSIL with HPV cytopathic effect, while other positive revealed CIN (II), i.e. HSIL with HPV cytopathic effect.

Low risk HPV cases revealed inflammatory Pap smears in two cases and atypical squamous cells with undetermined significance (ASCUS) in two cases.

PCR positive cases were observed in the age group of 1657 years.

\section{Age of marriage}

Age of marriage ranged from 16 years to 27 years.

In maximum cases $(41.6 \%)$, the age of marriage was 1921 years.

In patients positive for HPV DNA by PCR, the age was from 16 years to 26 years.

\section{Parity}

Amongst 36 cases, 6 cases (16.6\%) were primipara, 16 cases $(44.4 \%)$ were second para, 10 cases $(27.7 \%)$ were third para, 3 cases $(8.3 \%)$ were fourth para and 1 case $(2.77 \%)$ was sixth para.

In cases who were HPV DNA positive, 3 cases were para two, while one case each was para three, para six and para one.

\section{Immunocompromised status}

None of our patient was immunocompromised either by HIV or other causes. 


\section{Clinical examination}

Per speculum examination did not reveal significant change in any of these cases.

\section{Pap smear}

Out of 36 cases in 20 cases $(55.55 \%)$, the Pap smears revealed inflammatory pathology. There were 9 smears inadequate for opinion (25\%). In 3 cases Pap smear revealed atypical squamous cells with undetermined significance (ASCUS) (8.33\%), two of which were HPV DNA positive. Amongst them one revealed HPV change in smear. Remaining 4 cases were, case each of normal smear, atrophic vaginitis (AV), low grade squamous intraepithelial lesion (LSIL) with HPV change and high grade squamous intraepithelial lesion (HSIL) (2.77\%) (Figure 1-5 and Table 1).

Table 1: Cytological diagnosis.

\begin{tabular}{|ll|}
\hline Cytological diagnosis & Number of cases \\
\hline Normal smear & $1(2.77 \%)$ \\
\hline Inadequate smears & $9(25 \%)$ \\
\hline ASCUS & $3(8.33 \%)$ \\
\hline Atrophic vaginitis & $1(2.77 \%)$ \\
\hline LSIL & $1(2.77 \%)$ \\
\hline HSIL & $1(2.77 \%)$ \\
\hline Inflammatory & $20(55.55 \%)$ \\
\hline
\end{tabular}

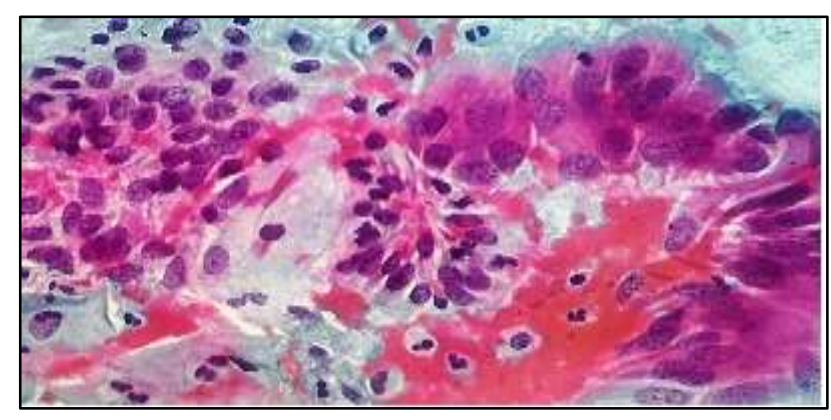

Figure 1: Endocervical cell with early squamous metaplasia with ASCUS (400x).

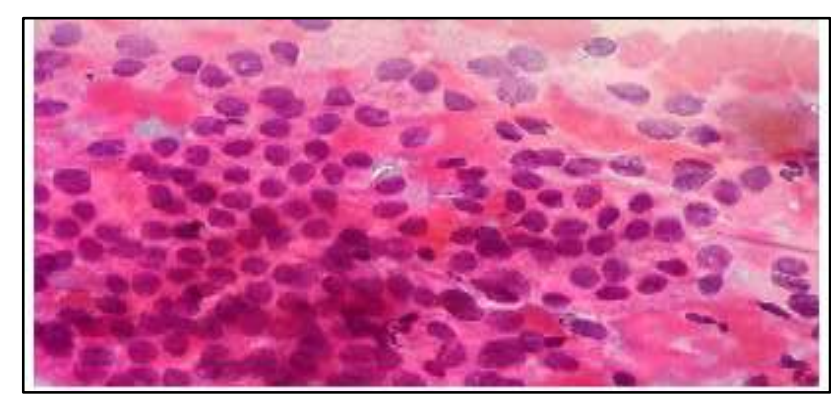

Figure 2: HSIL (400x).

Amongst 6 cases which were positive for HPV DNA, 2 cases each revealed ASCUS and inflammatory smears $(5.55 \%)$. One case each was showing LSIL and HSIL
(2.77\%). Cervical Pap smears revealed HPV changes in 4 of these cases in the form of Koilocytic change, nuclear irregularity and Dyskaryosis (66.6\%).

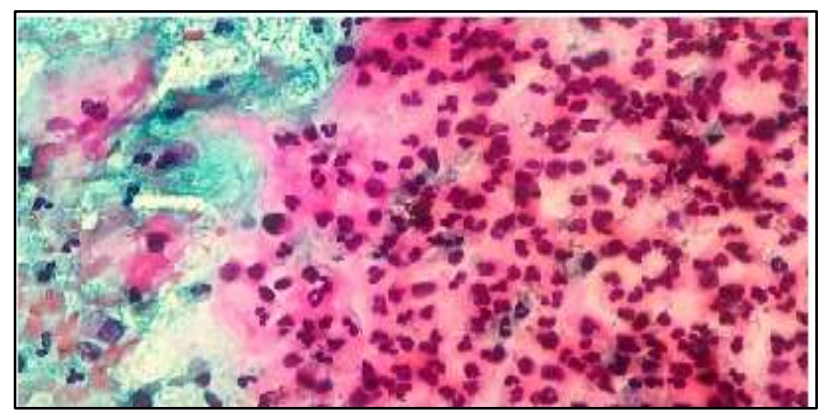

Figure 3: Inflammatory PAP smear (400x).

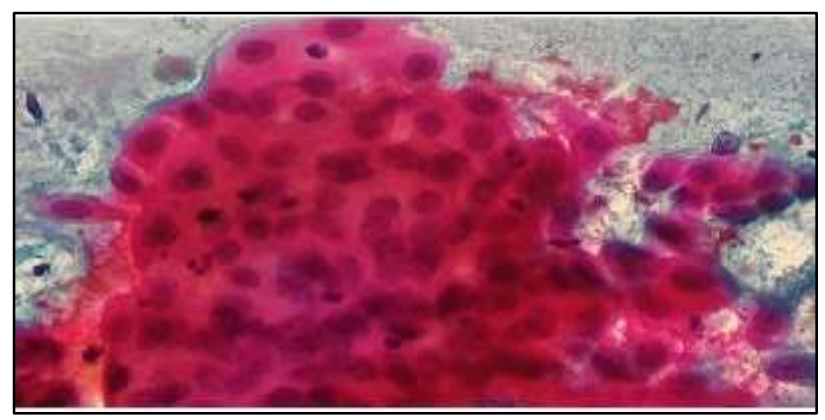

Figure 4: LSIL (400x).

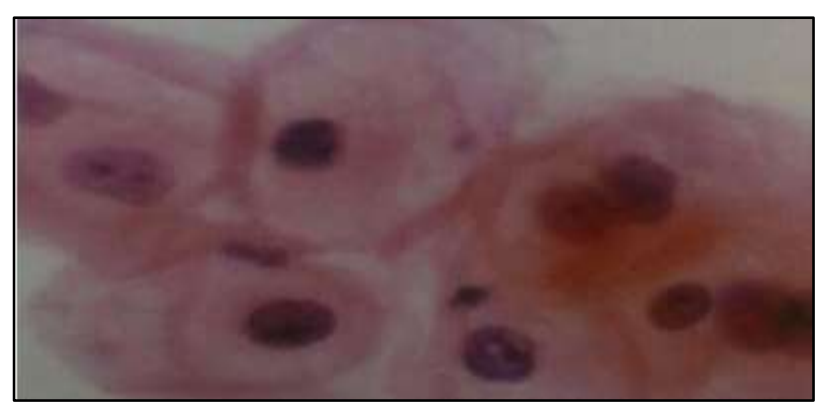

Figure 5: HPV changes (400x).

\section{Sensitivity and specificity}

Taking PCR as a gold standard, sensitivity, specificity, positive and negative predictive value of Pap smear was determined.

\section{Evaluation of a test}

- Sensitivity $=66.67 \%$

- Specificity $=100 \%$

- Predictive value of a positive test $=100 \%$

- Predictive value of a negative test $=93.75 \%$

- Percentage of false negative $=33.33 \%$

- Percentage of false positive $=0 \%$ 


\section{DISCUSSION}

The mean age of clinical presentation was 40 years in our study. The age of marriage ranged from 16 to 26 years in patients positive for HPV DNA by PCR. Amongst the two high risk HPV cases, the age of marriage was 19 years and 24 years, highlighting the risk factor of prolonged sexual intercourse as documented in literature. Both the cases were multipara, again increasing the risk of cervical cancer as stated in the literature.

Though per speculum examination in these cases did not reveal any significant lesion, Pap smear and PCR for HPV DNA detected abnormality. HPV DNA was detected in 6 cases out of total 36 cases $(16.4 \%)$, low risk - $11.1 \%$ and high risk- $5.5 \%$. Munoz N et al has reported this incidence as $13.4 \%$, while Kartigeyan $\mathrm{K}$ has reported it as $35 \%{ }^{6}$

High risk HPV in our demographic area was HPV 16. The non-oncogenic HPV serotypes were 6 and 11 in our study. High risk HPV resulted in CIN, while low risk HPV contributed to benign genital infections as documented by Karthigeyan K and Cramer HM et al. ${ }^{11,12}$ Two of these cases revealed only ASCUS and inflammation and no significant cytological change. Thus, HPV sequences can be found even in tissue lacking the morphological changes of HPV infection. Rest 4 cases revealed cytopathic changes in the form of koilocytic change, nuclear irregularity and dyskaryosis as observed in literature.

\section{CONCLUSION}

HPV DNA is detected in $16.4 \%$ of symptomatic patients. Low risk HPV cases predominate over high risk group Pap smears and PCR for HPV DNA testing are very useful in any detection of cervical lesions, where clinical examination has limitations to diagnose these lesions. Thus HPV DNA can be detected even in tissue lacking the morphological changes of HPV infection.

High risk HPV detection with the PCR technique can be used as a tool to identify the population at risk for subsequently development of cervical cancer. Thus HPV DNA testing can be added to cervical cytology for early detection of HPV infected patients at risk for cervical cancer.

\section{ACKNOWLEDGEMENTS}

Authors would like to acknowledge ICMR, Delhi for the proper guidelines and Department of Molecular and Genetic Laboratory of KIMSDU, Karad for technical support.
Funding: No funding sources Conflict of interest: None declared

Ethical approval: The study was approved by the Institutional Ethics Committee

\section{REFERENCES}

1. Schiffman M, Castle PE, Jeronion J, Rodrigue A, Wactolde S. Human papilloma virus and cervical cancer. Lancet. 2007:370:890-907.

2. Sankaranarayanan R, Ferlay J. Worldwide burden of gynaecological cancer. The size of the problem. Best Pract Res Clin Obstet Gynaecol. 2006;20:207-25.

3. WHO/ICO Information centre on HPV and cervical cancer (HPV Information Centre). Summary report on HPV and Cervical Cancer statistics in India; 2007.

4. Nobbenhuis M, Walboomers J, Helmerhorst T, Rozendaal L, Remmink A, et al. Relation of HPV status to cervical lesions and consequences for cervical cancer screening: a prospective study. Lancet. 1999;354:20-5.

5. Walboomers J, Jacob M, Manos M, Bosch F, Kummer J, Shah K, et al. Human papilloma virus is a necessary cause of invasive cervical cancer worldwide. J Pathol. 1999;189:12-9.

6. Munoz N, Bosch F, de San Jose S, Herrero R, Castellsague $X$, Shah $K$, et al. Epidemiologic classification of human papilloma virus types associated with cervical cancer. $\mathrm{N}$ Engl J Med. 2003;348:518-27.

7. Stormby N. Morphology of virus induced changes. $4^{\text {th }}$ European congress of cytology. Lsubljana; 1974.

8. Syrjanensm. Basic concepts of practical application of recombinant DNA techniques in detection of Human Papilloma Virus (HPV) infections APMIS. 1990;18:95-110.

9. Burrow OA, Howell LP, Hinricks S, Richard O. Cytomorphological features in the diagnosis of human papilloma virus infection of the uterine cervix. Acta Cytol. 1990;34:737-8.

10. Tanaka H, Chua KL, Lindh E, Hjerpe A. Patients with various types of human papilloma virus covariation and diagnostic relevance of cytological findings in Papanicolaou smears. Cytopathol. 1993;4:273-83.

11. Kaarthigeyan K. Cervical cancer in India and HPV vaccination. Indian J Med Paediatr Oncol. 2012:712.

12. Cramer H, Skinnes- Wannemuehler S, Brown D, Katz B, Fife K. Cytomorphological correlates of human papillomavirus infection in normal cervicovaginal smear. Acta cytol. 1997;41(2);261-8.

Cite this article as: Gurjar P, Patil N, Bonde V. Detection of human papilloma virus in the cervical Pap smears and with polymerase chain reaction technique in the rural area of Western Maharashtra, India. Int J Reprod Contracept Obstet Gynecol 2016;5:2648-51. 